http://dx.doi.org/10.18778/8142-006-8.06

\title{
Gender Stereotypes AND THE Place IDENTITY
}

\author{
MAGDALENA BANASIEWICZ
}

JAN RUSEK

Faculty of Psychology, University of Warsaw

This paper draws on a larger project we were working on in 2012 which explored the impact of the place cultural identity on the behaviour of coffeehouse customers and the dimension of femininity/masculinity proved to be essential to understanding the differences between coffeehouses. The article starts with discussing the concept of the place identity and its relation to gender. This section is followed by a brief presentation of the reciprocal relationships between perceptions of a given place and its users, and their possible effects. Then, we discuss the issue of gender stereotypes, the doctrine of two spheres, and stereotypical characteristics of a gendered space. Finally, we illustrate these issues with two case studies concerning the gendered public places.

A place is a geographical space filtered by human perception and past experiences. The contents of these cognitions - how a place is perceived and what meaning it conveys - constitute the place identity. Proshansky, Fabian and Kaminoff, in one of the first psychological papers on the concept, described the place identity as:

a sub-structure of the self-identity of the person consisting of, broadly conceived, (...) memories, ideals, feelings, attitudes, values, preferences, meanings, and conceptions of behaviour and experience which relate to the variety and complexity of physical settings that define the day-to-day existence of every human being, (...) a potpourri of memories, conceptions, interpretations, ideas, and related feelings about specific physical settings as well as types of settings. (59-60)

Although some authors point out to an individualistic bias in the psychological research on the place-identity (Dixon and Durrheim), the collective nature of relations between identities is evident. These cognitions themselves are personal, nonetheless, they occur in social contexts and they are facilitated by socialization. This generally makes them culturally shared, although Massey notes that places have no single, unique identities, and that 
the internal conflict lies in their nature (see: the case studies). Because places can be defined in terms of social relations, they are also highly dynamic (Massey).

In a word, the place identity can consist of an infinite variety of cognitions, limited only by the person's engagement with her environment (Proshansky). The infinite range of possible perceived traits of the environment allows the features to be arranged into configurations corresponding to cultural or stereotypical structures, such as gender. Moreover, its intertwinedness with personal and group identities suggests that the features defining social identities (such as gender) may also be important in the process of creating place identities.

The relationship between personal and space identity was researched by social scientists mainly as an instance of the impact of a context on one's perceptions and actions. For example, Guinote and Fiske analysed the way one's place of evaluation can exacerbate stereotyping, keeping with the category activation theory framework. In a different study, Gosling et al., inspired by the Egon Brunswik's "environment as lens" model, tried to explain how observers infer from personal environments the information about their occupants. In the model introduced by the authors, a two-step process links observers' perceptions of people's dispositions to their habitats. At either step, the observed phenomena (environmental residue or behaviour) can activate perception-influencing stereotypes. Socially shared stereotypical impressions are conditioned by the similarity of stereotypes held by observers, which is more probable for common stereotypes, such as those relating to one's race or gender.

The line of research discussed above suggests that elements of the physical environment which bring up associations with stereotypical femininity, such as certain colours or accessories, can lead to the stereotyping of people who use/ occupy that environment. This means that the physical space can not only be gendered, but also gendering, leading eventually to self-fulfilling prophecies, or even discrimination. The activation of stereotypes about the person's social group may also cause "a stereotype threat," that is anxiety about conforming to these activated stereotypes, which negatively affects one's performance in an array of disciplines. The presence of stereotype activating stimuli introduces a risk of self-stereotyping, which also affects self-evaluations and performance in related tasks.

Gender stereotypes are a very important and a wide field of research in psychology and social sciences. In the Gender Studies Encyclopedia, stereotypes are defined as "fixed, popular images of particular phenomena or social groups, usually simplified in the cognitive layer and strongly axiologically and emotionally marked" (Lisowska 520). Specifically, gender 
stereotypes consist of beliefs about one's mental qualities, behaviour, appearance, profession and other characteristics of men and women (Brannon).

Origins of gender stereotypes and their influence on the social life and lives of individuals are not easy to investigate. It is believed that gender stereotypes have no connection with any innate or biological features of women and men, but they are closely related to socially constructed gender roles and patterns of masculinity and femininity (Brannon). On the other hand it is false to believe that gender stereotypes are completely divergent from reality. They play a role in shaping beliefs, attitudes and behaviour - also in stereotyped groups through imitation and attempting to adapt to a pattern (Lisowska). Some authors believe negative stereotypes to be an instrument of power over the stereotyped groups. In particular stereotypes of women play a role in maintaining patriarchy and help men to retain their privileged position and power in society (Vianello and Caramazza).

As in the case of modern stereotypes about women, the duality of women's and men's spheres was born in the nineteenth century. Because of the industrial revolution, the way of living in many upper and middle class families in Europe and North America has changed. Men started to work mostly outside the house and women took care of home and children. That was also the time when the cult of "true womanhood" was born, with piety, purity, submission and domesticity as four virtues of "true women." Consequently, man was meant to display opposite qualities-hardness, confidence, high position and even aggressiveness (Brannon).

The doctrine of two spheres assumes that women and men have separate spheres of influence. According to the doctrine, women are meant to stay at home and take care of the family and house, whereas men are dedicated to the outside world and work (Brannon). This of course, had a huge effect on segregation relating to space, and other inequalities. Modern studies confirm that the spatial gender segregation still correlates with the lower social status of women in relation to men's status (Spain). It also means the physical separation of women from valuable knowledge and other resources. Gendered spaces usually reinforce the status quo in genders' status differences which are taken for granted. In reality, this often means limiting women's power over space to the boundaries of the household, or even only the kitchen.

The two spheres doctrine can be found in some modernist architects' works which were interpreted as products of beliefs about gender identities, i.e. that domestic buildings' exterior façades mirror the part of masculine 
identity hiding its feminine side (the interior), and as such should separate it from the outside. This was criticised for failing at the level of gender equality and implicitly attributing the public sphere to men, while maintaining that woman's place is in the home (Rice).

Attempts to overcome the distinction took the form of, for example, publishing guide books. The Przestrzen Kobiet Foundation designs sightseeing routes in Polish cities to show the connections between women's movement and the public space (Furgał). Since Polish name for travel guides, przewodnik, means "male tour guide," the foundation subversively publishes the series under the name przewodniczka, "the woman guide" (full title was Szlaki kobiet. Przewodniczka po Polsce emancypantek). Other efforts include postulating renaming streets after famous women (Miloch), and entrepreneurial work, which is discussed in further detail later.

There are many stereotypes about how women's and men's space should look like, or how it often looks like. For instance, features of the home interior design have been associated with the femininity - masculinity dimension. Not surprisingly, the characteristics frequently associated with particular genders predominantly correspond to underlying perceptions of stereotypical gender characteristics, and not so much to specific pieces of furniture or decoration. For example, "manly" design is often characterised by roughness (raw materials), simplicity (straight lines) and dominance over nature (antlers, hunting trophies, leather) (Mitchell). On the other hand, femininity in design is often defined as fragility (flowery patterns) and comfortability (soft materials).

These features can be seen as a continuation of nineteenth century stereotypes and ideals of femininity and masculinity: the stereotype of a woman as a domesticated, pure and innocent creature, and the stereotype of a man as strong, imperious and bearish (Brannon). In an article published by the online housing magazine Curbed, entitled "It's Time to Stop Describing Spaces as 'Masculine' or 'Feminine," the authors argue that gender labelling of the living space by design writers may have a negative impact on the readers less comfortable with current societal expectations concerning gender roles. This is in line with the research on stereotype facilitation by elements of the physical setting, discussed above. The authors noted that masculinity is often characterised by rawness, while femininity is considered to be of an "additive," embellishing nature, translated to decorative efforts, including flowers, lace, stemware, etc. A place, then, seems to belong to men's sphere by default, whereas women need to put in extra work in an effort to take possession of the public (or virtually any) space. Indeed, women were found to use more personal items in order to personalise their private offices (Dinç). 
Although sex differences were reported with regard to functioning of the visual system (Abramov et al.), and, for example, the impact of the room light on cognitive processes (Knuz), there are no biological explanations for gender stereotypes concerning space. However, it is probable that these views are being reinforced since one's early childhood, for example, by providing girls and boys with toys and accessories that differ in various respects, and especially in colour ("pink for girls, blue for boys") (Pomerleau).

The following article would like to present two examples of gendered places, which, in our opinion, illustrate well the issues discussed above. Babie Lato café was founded in 2004 in Częstochowa. Its name is a word pun and could be understood as "spider kiting," but also "women's summer." The place no longer exists, but, at that time, similar cafes in other Polish cities were established. It was a place set up by women, employing only women and dedicated to women clientele. As one can read on the website advertising the place: "Here we do not have to listen to conversations about cars, mechanics, fights with the traffic police, or the results of football matches, and who can drink more alcohol. Here we can talk about children, bras cuts, whether a sweater is pleasant to the touch, and athletes-but not about their results, but whether they looked nice in shorts" ("Babie lato"). The decor of the premises was also peculiar. On their official website ("Babie lato"), there are several archival photographs of the interior showing many different shades of pink dispersed over the walls and floor. On the table, at the entrance, pink flowers were placed, and over the table golden balloons hung down from the ceiling. A different picture shows images of female models plastered on the walls and a poster advertising a male erotic dancers' show.

What is important, men could enter the premises only with a colourful wig put on, which effectively discouraged many men from spending time there. One such a visit without a wig ended up even in court. A male client did not want to wear a wig and he was not admitted to the premises by the waitress. The court saw no discrimination in these actions and explained that economic freedom was in force and the café owners could direct their services to whom they wanted (Drywa). One of the owners commented on that situation: "He wanted to make a fuss and he did it. We do not try to get into nightclubs for gentlemen. If they (men) don't want to come, they don't have to. Is it really so dishonourable to wear a colourful wig?" (Ogórek).

From the cafe's description on the website, there emerges a very black and white picture of the feminine and masculine worlds. Women and men in the eyes of the owners have completely different interests and worldviews, and they did not understand the troublesome client. The place's interior 
design is depicted as stereotypically feminine and the café itself may be even seen as a type of extension of the house, which is traditionally considered to be a women's place (Brannon). Maybe a café for women had to be stereotypically feminine since it is hard to indicate any other patterns of femininity? Unfortunately, according to social studies discussed earlier, this could lead to stereotyping the patrons, and subsequent negative psychological consequences.

On the other hand, for women, public places may serve as an escape from domesticity, male dominance and control. For example, public and semipublic spaces like department stores or coffee shops for many women are spaces of freedom from classic roles of a housewife and mother (McDowell). Statements from the café owners confirm this assumption-they say that their café is a place where women may freely enter in their casual outfit, without makeup and are free from men's talk (Ogórek). It is also noteworthy that the business was established by forty women, and a role of a businesswoman is far less stereotypical than a businessman. Babie Lato café provided a partial emancipation both for their owners and clients. It was an attempt of going beyond the stereotype of a good mother and housewife, but eventually it ended up still being trapped in stereotypes.

Another example is a male hairdresser's salon from Gdańsk, under the name of The Barbers. In April 2017, the place became known after one woman wrote a letter to a newspaper and described a situation in which she was asked to leave the premises because of her gender (Rychcik). The woman accompanied her friend, however, the workers stated that women were not allowed inside and firmly asked her to leave. The woman was also shown a sticker on the counter with a crossed-out woman's silhouette. The woman felt offended and discriminated against. A person associated with the barbershop commented on the situation as follows: "We do not prohibit admission to women, we only ask them to leave the establishment. The reason? Our lounge is very small and customers complained about the loud behaviour of waiting partners of other clients. They said they didn't feel free to discuss men's issues. Since we introduced this principle, the gentlemen feel comfortable and it created a nice atmosphere, which our customers praise very much" (Włodkowska).

The decor of the shop, judging from the promotional photos from The Barbers' page published on Facebook ("The Barbers"), is in many ways stereotypically masculine (Mitchell). The interior is raw and industrial with the wooden board on the floor, exposed bare red bricks at the walls, and leather armchairs for clients. Additional decorations come down to several items hung on the walls: a bicycle and a few black and white photos. Among many promotional pictures showing the interior or the barbers at work, there 
are two photos with a sexist theme. One of them shows a client reading Playboy magazine while having his hair cut. The second one, carefully arranged, presents a client sprawled out in an armchair while a young woman dressed in a corset, stockings and high heels is shaving his legs. In that same page the fact that place is dedicated to men is very strongly emphasised: "Male (and only male) hairdresser's salon. We cut hair, shave beards, advise in care."

Barbershops (such as the one in the photograph, see fig. 1) seem to give men a sense of belonging to the male community where they can celebrate "manhood," feel manlier and enhance their male identity (Brett, Al-Assaf). Masculinity is possibly the most important piece of barbershops' place identities. But there is also the other side of the coin, and that is consolidating the existing gender roles and resisting changes in attitudes and stereotypes toward women. Franklin explored it during his insightful research conducted in the 1980s in the male Black barbershop, based on "participant-asobserver" methodology. He showed how important masculinity is in such a place, and how clients and barbers negotiate and discuss gender roles. Conversation topics taken up in the barbershop varied, nevertheless, the issues of gender roles and male-female relationships predominated.

Stereotypes about males and females were strongly visible in conversations at the barbershop investigated by Franklin. Common themes included, for instance: the behaviour of women is based on emotions and instinct whereas men act in accordance with logic; women get raped because they ask for it; women should stay at home and take care of children and the house. Significant individuals in the barbershop setting presented a promasculine perspective. It included many stereotypically masculine features: toughness, decisiveness, self-control, powerfulness, aggressiveness, and above all the "No Sissy Stuff" aspect of masculinity, which means a complete separation from stereotypically feminine characteristics and the denial of any feminine side of self. There was an unwritten rule in the barbershop, and that was "to establish sufficient distance from femininity." The language used by male clients was also noteworthy, often vulgar with the persistent rendering of sexual epithets defining women, devaluing femininity and placing women in a submissive position. When females occasionally entered the shop, the climate quickly changed, conversations stopped, subjects were changed and voices were muted. 


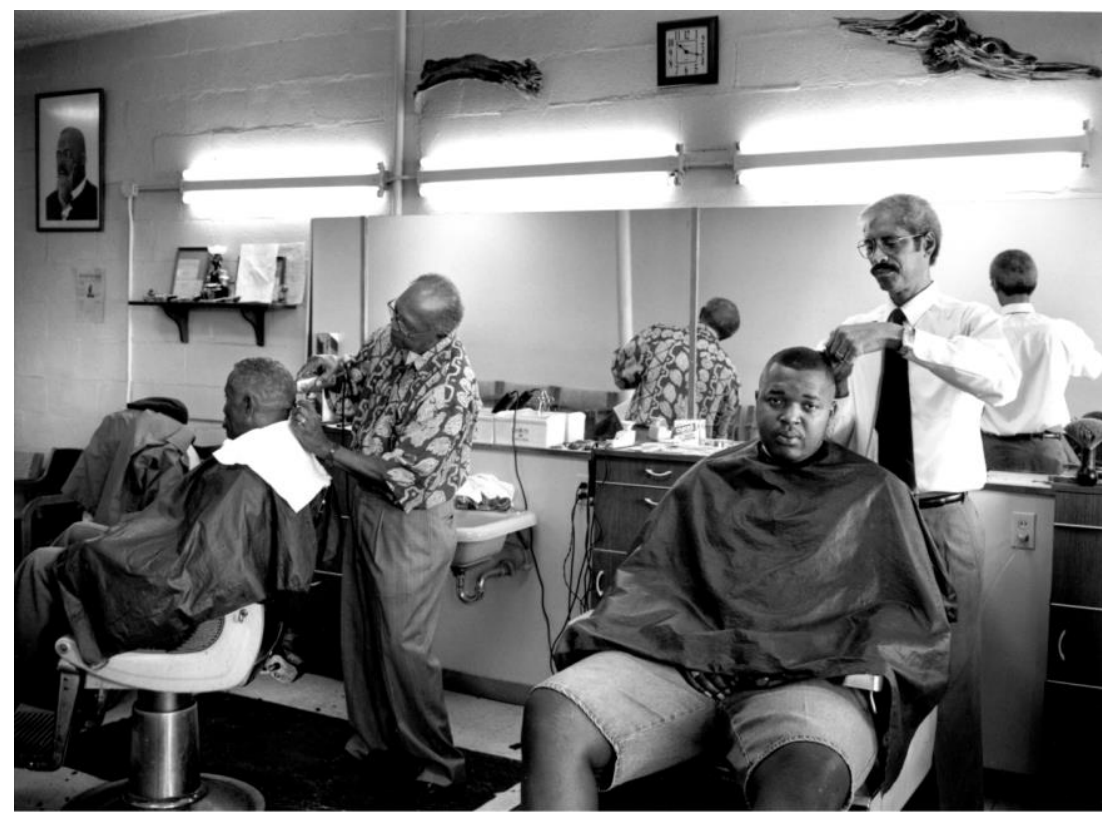

Deluxe Barbershop

Business partners Alonzo Roberts and James Chandler have been giving haircuts at the Deluxe Barbershop for 50 and 39 years, respectively. Original owners included James Dixon, Jr. and Bill Hardy, who operated a barbershop in the same location around the turn of the century. In March of 1995, the current owners moved across the street to the northside of the square. The newly constructed building will continue the one-hundred-year old tradition of a continuously operated barbershop in Hannibal Square.

Fig. 1. Peter Schreyer, Deluxe Barbershop, Winter Park Public Library, USA, 1995

In the case of The Barbers, excluding women is the best proof of distancing from femininity. Only when they excluded women from the shop's space, the clientele felt free to discuss "manly" topics (and what topics are manly?). Also their sexist promotional photos show a devaluing approach to women. Nonetheless, we do not have enough information about staff and clients behaviour to say, how they understand gender roles. Franklin's case study is not enough to draw conclusions about The Barbers, but it provides threads that are worth exploring. It would be very interesting to conduct the research similar to Franklin's, but at a present-day barbershop. All in all, barbershops 
may still be the habitats of gender stereotypes, but they may not be as strong as thirty years ago, and definitions of masculinity and femininity surely have evolved during this time.

To sum up, we would like to recommend further steps necessary to understand relations between the place identity, gender stereotypes and the gendering of places. This is necessary if we want to fight with negative phenomena such as gender discrimination and gender stereotypes. The high quality quantitative and qualitative research in these fields is needed. As our case studies showed, gendering places may lead to the discrimination and exclusion of persons identifying with other genders. It is possible that when stereotypically constructed gender is an important part of the place identity, gender exclusion and discrimination is more common in that place. What is interesting, it seems that the place identity of "feminine" places may be in different relations with gender stereotypes than in case of "masculine" places. Babie Lato café in some ways contradicted gender stereotypes about women, whereas The Barbers barbershop celebrated stereotypes of masculinity. These are just hypotheses that would need verification during research and there are many more threads worth exploring.

Psychologists really do not fully realise how important role the physical environment plays when it comes to forming and reinforcing gender stereotypes and all the other psychological phenomena linked to it. While conducting such research, it would be favourable to cooperate with initiatives striving for gender equality in the public space. Conclusions would be very useful in overcoming the potentially negative aspects of gendering places and places connected gender stereotypes. It could also help improving the quality of public spaces and decreasing gender related discrimination. In the environmental psychology, the aspect of gender is still not pronounced loud enough and it needs to change.

We would like to thank the Przestrzen Kobiet Foundation for donating their publications, which were a valuable source of information and inspiration. 


\section{Works Cited}

Abramov, Israel, et al. "Sex \& Vision I: Spatio-Temporal Resolution." Biology of Sex Differences, vol. 20, no. 3, 2012.

Al-Assaf. "Why Men Need To Save The Barbershop Culture." Return of Kings, 25 Oct. 2014, www.returnofkings.com/46142/on-the-barbershopculture. Accessed 30 May 2017.

"Babie Lato.", www.babielato.wartobyc.pl. Accessed 17 May 2017.

"The Barbers." https://pl-pl.facebook.com/thebarbersgdansk/. Accessed 30 May 2017.

Brannon, Linda. Psychologia rodzaju. Trans. Magdalena Kacmajor. Gdańskie Wydawnictwo Psychologiczne, 2002, pp. 211-240.

Brett. "Why Every Man Should Go to a Barbershop." The Art of Manliness, 20 May 2008, www.artofmanliness.com/2008/05/20/rediscovering-thebarbershop/. Accessed 30 May 2017.

Dinç, Pınar. "Gender (In)difference in Private Offices: A Holistic Approach for Assessing Satisfaction and Personalization." Journal of Environmental Psychology, vol. 29, no. 1, 2009, pp. 53-62.

Dixon, John, and Kevin Durrheim. "Dispacing Place-Identity: A Discursive Approach to Locating Self and Other." British Journal of Social Psychology, vol. 39, no. 1, 2000, pp. 27-44.

Drywa, Łukasz. "Sąd: kafejka wyłącznie dla kobiet dozwolona." Gazeta.pl Wiadomości, 13 Jul. 2011, www.wiadomosci.gazeta.pl/wiadomosci/1,114 873,3079784.html. Accessed 17 May 2017.

Franklin, Clyde. "The Black Male Urban Barbershop as a Sex-Role Socialization Setting." Sex Roles, vol. 12, no. 9, 1985, pp. 965-979.

Furgał, Ewa, editor. Szlaki kobiet. Przewodniczka po Polsce emancypantek. Fundacja Przestrzeń Kobiet, 2015.

Gosling, Samuel D., et al. "A Room With a Cue: Personality Judgments Based on Offices and Bedrooms." Journal of Personality and Social Psychology, vol. 82, no. 3, 2002, pp. 379-398.

Guinote, Ana, and Susan T. Fiske. "Being in the Outgroup Territory Increases Stereotypic Perceptions of Outgroups: Situational Sources of Category Activation." Group Processes \& Intergroup Relations, vol. 6, no. 4, 2003, pp. 323-331.

"It's Time to Stop Describing Spaces as 'Masculine' or 'Feminine." Curbed, 15 Dec. 2014, www.curbed.com/2014/12/15/10012002/masculinefeminine-design-decor-writing. Accessed 5 May 2017.

Knuz, Igor. "Effects of Colour of Light on Nonvisual Psychological Processes." Journal of Environmental Psychology, vol. 21, no. 2, 2001, pp. 201-208. 
Lisowska, Ewa. "Stereotyp." Encyklopedia gender, edited by Monika RudaśGrodzka et al, Czarna Owca, 2014, pp. 520-524.

Massey, Doreen. Space, Place, and Gender. Polity, 1994, pp. 146-156.

McDowell, Linda. Gender, Identity and Place. Understanding Feminist Geographies. University of Minnesota Press, 2003, pp. 148-170.

Miloch, Maja. "Kobiety na patronki ulic." WP Kobieta, 6 Mar. 2017, www.kobieta.wp.pl/kobiety-na-patronki-ulic-6098226018456193a. Accessed 30 May 2017.

Mitchell, Nancy. "His and Hers: Analyzing "Masculine" and "Feminine" Decor." Apartment Therapy, 6 Oct. 2013, www.apartmenttherapy.com/his -and-hers-analyzing-masculine-and-feminine-decor-193542. Accessed 5 May 2017.

Ogórek, Katarzyna. "Babie Lato - udany biznes kobiet pracujących." WP Money, 28 Jun. 2006, www.manager.money.pl/strategie/case_study/ artykul/babie;lato;-;udany;biznes;kobiet;pracujacych,19,0,168211.html. Accessed 17 May 2017.

Pomerleau, Andrée, et al. "Pink or Blue: Environmental Gender Stereotypes in the First Two Years of Life." Sex Roles, vol. 22, no. 5, 1990, pp. 359-367.

Rice, Charles. The Emergence of the Interior: Architecture, Modernity, Domesticity. Routledge, 2007, pp. 96-97.

Proshansky, Harold M., et al. "Place-identity: Physical World Socialization of the Self." Journal of Environmental Psychology, vol. 3, no. 1, 1983, pp. 57-83.

Rychcik, Julia. “Zakaz wprowadzania kobiet, to tylko żart?” Wyborcza.pl, 7 Apr. 2017, www.wyborcza.pl/7,95891,21606798,zakaz-wprowadzaniakobiet-to-tylko-zart.html. Accessed 17 May 2017.

Schreyer, Peter. Deluxe Barbershop, Winter Park Public Library, USA, 1995. Vianello, Mino, and Elena Caramazza. Gender, Space and Power. Bookchase, 2005.

Włodkowska, Katarzyna. "Zakaz wstępu dla kobiet do salonu fryzjerskiego [DYSKUSJA]." Wyborcza.pl Trójmiasto, 12 Apr. 2017. www.trojmiasto. wyborcza.p1/trojmiasto/7,35612,21618578, gdansk-zakaz-wprowadzaniakobiet-do-salonu-fryzjerskiego-dyskusja.html\#Czolka3Img. Accessed 17 May 2017. 